\title{
POLA PENDERITA RAWAT INAP THT-KL DI BLU RSUP PROF. DR. R. D. KANDOU MANADO PERIODE JANUARI 2010 - DESEMBER 2012
}

\author{
${ }^{1}$ Christo E. Kandouw \\ ${ }^{2}$ Ora I. Palandeng \\ ${ }^{2}$ Steward Mengko \\ ${ }^{1}$ Kandidat Skripsi Fakultas Kedokteran Universitas Sam Ratulangi \\ ${ }^{2}$ Bagian Ilmu THT-KL BLU Universitas Sam Ratulangi \\ Email: Kandowchristo@gmail.com
}

\begin{abstract}
Indonesia is currently in the middle of the epidemiological transition in which noncommunicable diseases have increased dramatically while infectious diseases are still the major causes of disease. Epidemiological transition, which is marked by the growing of degenerative diseases and certain diseases associated with throat-ear-nose head and neck Surgery (ENT-HNS) that can not besolved completely. This study aimed to assess the pattern of hospitalized patients of the ENT-HNS in Prof. Dr. R. D. Kandou Hospital Manado. This was a descriptive retrospective study. Samples were all patients hospitalized in the ENT-HNS Department of Prof. Dr. RD Kandou Hospital Manado from January 2010 to December 2012. The results showed that based on the types of diseases there were 239 cases of throat infection (55.97\%), 163 cases of nasal diseases (38.17\%) and 25cases (5.85\%) of ear diseases. The highest percentage of types of disease was acute pharyngitis with 75 cases $(17.48 \%)$ and the lowest ones were laryngeal abscess, tongue abscess, adenotonsilitis, cancer of nasal cavity, cvancer of left external ear, acute epiglottis, infiltrated peritonsilar, tonsilectomy, polyps, tumors of the tongue, vocal cords tumors, ear tumors, and tumors of tonsil and pharyng each of 1 case (0.23\%). Conclusion: There were 48 types of diseases and the 10 diseases with the highest percentages consecutively were acute pharyngitisis, epistaxis, polyps of nasal cavity nasopharyngeal cancer, tumors coli, larynx tumors, tonsilopharyngitis, laryngitis, and sinusitis.
\end{abstract}

Keywords: ENT-HNS diseases, hospitalized patients

\begin{abstract}
Abstrak: Indonesia saat ini berada pada pertengahan transisi epidemiologi dimana penyakit tidak menular meningkat drastis sementara penyakit menular masih menjadi penyebab penyakit yang utama. Transisi epidemiologis, yang di tandai dengan semakin berkembangnya penyaki degeneratif dan penyakit tertentu temasuk penyakit yang berhubungan dengan Telinga Hidung Tengorokan Bedah Kepala Leher (THT-KL). Penelitian ini bertujuan untuk mengetahui pola penyakit penderita rawat inap SMF THT-KL di RSUP Prof. Dr. R. D. Kandou Manado periode Januari 2010 sampai dengan Desember 2012. Penelitian ini menggunakan metode deskriptif restropektif. Populasi penelitian ialah penderita rawat inap di RSUP Prof. dr. R. D. Kandou Manado. Sampel ialah seluruh penderita rawat inap di SMF THT-KL di RSU Prof. dr. R. D. Kandou Manado dari periode Januari 2010 - Desember 2012. Hasil penelitian memperlihatkan jenis penyakit berdasarkan penyakit tenggorokan ada 239 kasus (55,97\%), penyakit hidung 163 kasus (38,17\%) dan penyakit telinga 25 kasus (5,85\%). Jenis penyakit terbanyak ialah faringitis akut dengan 75 kasus ( 17,48\% ) dan terendah abses laring, abses lidah, adenotonsilitis, Ca cavum nasi, Ca MAE Sinistra, epiglottis akut, infiltrat peritonsiler, polip tonsiltektomi, tumor lidah, tumor plika vokalis, tumor telinga, dan tumor tonsil faringitis masing-masing 1 kasus ( 0,23\% ). Simpulan: Dari pasien rawat inap periode 2010-2012 berdasarkan jenis penyakit, didapatkan 48 jenis penyakit dengan 10 penyakit THT-KL terbanyak, yaitu berturut-turut: faringitis akut, epistaksis, tonsilitis, polip nasi, Ca nasofaring, tumor coli, tumor laring, tonsilofaringitis, laringitis, dan sinusitis.
\end{abstract}

Kata kunci: THT-KL, penderita rawat inap 
Terselenggaranya pelayanan kesehatan yang lebih bermutu dan merata untuk seluruh masyarakat merupakan keinginan yang menjadi landasan pelaksanaan pembangunan kesehatan di Indonesia. Pembangunan kesehatan di Indonesia selama beberapa decade yang lalu harus diakui relatif berhasil, terutama pembangunan infra struktur pelayanan kesehatan yang menyeluruh sebagian besar wilayah kecamatan dan pedesaan. Namun keberhasilan yang sudah dicapai belum dapat menuntaskan problem kesehatan masyarakat secara menyeluruh, bahkan sebaliknya tantangan sektor kesehatan cenderung semakin meningkat. Indonesia saat ini berada pada pertengahan transisi epidemiologi dimana penyakit tidak menular meningkat drastis sementara penyakit menular masih menjadi penyebab penyakit yang utama. Kemudian saat ini penyakit kardiovaskuler (jantung) menjadi penyebab dari 30 persen kematian di Jawa dan Bali. Indonesia juga berada diantara sepuluh negara di dunia dengan penderita diabetes terbesar. Di saat bersamaan penyakit menular dan bersifat parasit menjadi penyebab dari sekitar 22 persen kematian. Angka kematian ibu dan bayi di Indonesia juga lebih tinggi dibandingkan dengan kebanyakan negara tetangga. Satu dari dua puluh anak meninggal sebelum mencapai usia lima tahun dan seorang ibu meninggal akibat proses melahirkan dari setiap 325 kelahiran hidup. Perubahan yang diiringi semakin kompleksnya pola penyakit merupakan tantangan terbesar bagi sistem kesehatan di Indonesia. Transisi epidemiologis, yang di tandai dengan semakin berkembangnya penyaki degeneratif dan penyakit tertentu temasuk penyakit yang berhubungan dengan Telinga Hidung Tengorokan Bedah Kepala Leher (THT-KL) yang belum dapat diatasi sepenuhnya, merupakan sebagian tantangan kesehatan. Tantangan lainnya yang harus ditanggulangi antara lain adalah meningkatnya masalah kesehatan kerja, kesehatan lingkunngan, masalah obatobatan dan perubahan dalam bidang ekonomi, kependudukan, pendidikan, sosial budaya dan dampak globalisasi yang akan memberikan pengaruh terhadap perkembangan keadaan kesehatan masyarakat. Hal ini akan berdampak pada terganggunya kesehatan masyarakat yang membawa masyarakat untuk pergi berobat baik secara rawat jalan maupun pada kondisi tertentu dapat pula dilakukan rawat inap. ${ }^{1-3}$

Berdasarkan data Kesehatan Indonesia, penyakit rawat inap di rumah sakit tahun 2010 yang berhubungan dengan kasus THT-KL untuk laki-laki 54,34\% atau 9.737 kasus dan perempuan $45,66 \%$ atau 8.181 kasus. Penelitian lain yang dilaksanakan pada tahun 2004-2007 di Instalasi Rawat Jalan THT-KL RSU Prof. Dr. R.D. Kandou Manado, jumlah pasien yang berkunjung semakin bertambah dengan rata-rata kunjungan 6714 pasien/tahun. Ada 10 penyakit terbanyak seperti, serumen obsturans, otitis eksterna, sinusitis, faringitis kronik, faringitis akut, rinitis alergi, corpus alineum MAE, presbyakusis, rinitis akut dan otitis media akut., ${ }^{3,4}$

Pada poliklinik THT RSU Prof. Dr. R. D. Kandou Manado, berdasarkan penelitian pada tahun 2002-2003 dengan jumlah kunjungan rata-rata 4429 pertahun, disimpulkan bahwa perbandingan persentasi penyakit telinga:hidung: tenggorok ialah 47,62 : 32,02 : 20,36. Terdapat 10 penyakit THT terbanyak, yaitu: otitis eksterna, rhinitis akut, rhinitis kronik, otitis media kronik, otitis media akut, faringitis kronik faringitis akut, rhinitis vasomotor, sinusitis maksilaris dan presbiakusis.

Dalam kurun waktu 4 tahun ditempat yang sama tahun 2007 didapatkan 26.854 pengunjung di poli THT dan ditemukan kasus baru sebanyak 12.344. Dari jumlah kasus baru yang ditemukan, disimpulkan bahwa perbandingan persentasi penyakit telinga : hidung : tenggorok ialah 51,67: 30,14: 18,14. Terdapat 10 penyakit terbanyak rhinitis kronik, otitis eksterna, rhinitis akut, otitis media kronik, faringitis kronik, benda asing MAE, otitis media akut, tonsillitis akut, presbiakusis, dan rhinitis alergika. ${ }^{5}$

Hal ini menunjukkan terjadinya pergeseran pola penyakit pada masyarakat 
Indonesia, sehingga perlu dilaksanakan penelitian yang teliti dan lengkap. Evaluasi pola penyakit penderita dalam kurun waktu tertentu guna kepentingan data epidemiologi, diagnosis, terapi dan pencegahan. Selain itu untuk membantu pencatatan dan pelaporan penderita THTKL, bukan hanya penderita rawat jalan, namun juga penderita rawat inap perlu dilakukan pendataan guna mendukung system kesehatan yang lebih baik lagi di masa mendatang. ${ }^{3}$

\section{METODE PENELITIAN}

Penelitian ini menggunakan metode deskriptif restropektif. Penelitian dilakukan di Bagian Ilmu THT-KL BLU RSUP Prof. Dr. R. D. Kandou Manado. Populasi penelitian ialah penderita rawat inap di RSU Prof. Dr. R. D. Kandou Manado dan sampel yang digunakan ialah seluruh penderita rawat inap di SMF THT-KL di RSU Prof. Dr. R. D. Kandou Manado dari periode Januari 2010 - Desember 2012.

\section{HASIL PENELITIAN DAN BAHASAN Sosiodemografi}

Karakteristik pasien rawat inap SMF THT-KL RSUP Prof. Dr. R. D. Kandou tahun Januari 2010 sampai Desember 2012 berdasarkan sosiodemografi yang terdiri dari: umur dan jenis kelamin, agama, suku, tingkat pendidikan dan pekerjaan dapat dilihat pada Tabel 1. Berdasarkan umur dan jenis kelamin yang terbanyak pada kelompok umur 40-49 tahun sebesar 35,56\% yang terdiri dari laki-laki 18,49\% dan perempuan $17,07 \%$. Pasien rawat inap yang terendah terdapat pada kelompok umur kurang dari 1 tahun 6,1\% yang terdiri dari laki-laki 1,13 dan perempuan 4,88\%.

Tabel 1. Distribusi Pasien Rawat Inap SMF THT-KL Berdasarkan Sosiodemografi Di RSUP Prof Dr. R. D. Kandou Manado Tahun 2010-2012

\begin{tabular}{llllll}
\hline \multirow{2}{*}{ No } & Umur & & & & \\
dan & Jenis & Laki-Laki & Perempuan & Jumlah \\
\cline { 2 - 4 } & Kelamin & F & $\%$ & F & $\%$ \\
\end{tabular}

\begin{tabular}{ccccccc}
\hline 1 & $<1$ & 3 & 1,13 & 8 & 4,88 & 11 \\
2 & $1-9$ & 32 & 12,08 & 39 & 23,78 & 71 \\
3 & $10-19$ & 27 & 10,19 & 20 & 12,20 & 47 \\
4 & $20-29$ & 26 & 9,81 & 19 & 11,59 & 45 \\
5 & $30-39$ & 32 & 12,08 & 22 & 13,41 & 54 \\
6 & $40-49$ & 49 & 18,49 & 28 & 17,07 & 77 \\
7 & $50-59$ & 46 & 17,36 & 18 & 10,98 & 64 \\
8 & $60-69$ & 30 & 11,32 & 6 & 3,66 & 36 \\
9 & $>70$ & 20 & 7,55 & 4 & 2,44 & 24 \\
& Total & 265 & 100 & 164 & 100 & 429 \\
\hline
\end{tabular}

Berdasarkan agama yang terbanyak ialah Kristen protestan 88,68\% dan yang terendah agama katolik 2,10\% (Tabel 2). Berdasarkan suku yang terbanyak ialah suku Minahasa yaitu 82,28\% dan terendah ialah suku Bantik, Ambon dan Tiong Hoa yaitu 0,47\%, 0,70\% dan 0,93\% (Tabel 3). Berdasarkan tingkat pendidikan yang terbanyak ialah SLTA 48,95\% dan yang terendah SLTP (Tabel 4). Berdasarkan pekerjaan yang terbanyak ialah belum atau tidak berkerja 23,08\% dan yang terendah sopir dan pekerja tidak tetap yaitu 0,70\% dan 1,17\% (Tabel 5).

Tabel 2. Distribusi Pasien Rawat Inap SMF THT-KL Berdasarkan agama

\begin{tabular}{cccc}
\hline No & Agama & F & $\%$ \\
\hline 1 & Kristen Protestan & 359 & 83,68 \\
2 & Kristen Katolik & 9 & 2,10 \\
3 & Islam & 61 & 14,22 \\
& Total & 429 & 100 \\
\hline
\end{tabular}

Tabel 3. Distribusi Pasien Rawat Inap SMF THT-KL Berdasarkan suku

\begin{tabular}{clcc}
\hline No & Suku & F & $\%$ \\
\hline 1 & Ambon & 3 & 0,70 \\
2 & Bantik & 2 & 0,47 \\
3 & Bolmong & 5 & 1,17 \\
4 & Gorontalo & 13 & 3,03 \\
5 & Jawa & 6 & 1,40 \\
6 & Minahasa & 353 & 82,28 \\
7 & Sanger & 25 & 5,83 \\
8 & Siau & 9 & 2,10 \\
9 & Talaud & 9 & 2,10 \\
10 & Tiong Hoa & 4 & 0,93 \\
Total & & 429 & 100 \\
\hline
\end{tabular}


Kandouw, Palandeng, Mengko: Pola penderita rawat...

Tabel 4. Distribusi Pasien Rawat Inap SMF THT-KL Berdasarkan pendidikan

\begin{tabular}{llcc}
\hline No & Pendidikan & F & $\%$ \\
\hline 1 & Belum/Tidak Sekolah & 81 & 18,88 \\
2 & SD & 52 & 12,12 \\
3 & SLTP & 27 & 6,29 \\
4 & SLTA & 210 & 48,95 \\
5 & Akademi/Perguruan & 59 & 13,75 \\
\multicolumn{2}{l}{ Total } & & \\
& Tinggi & 429 & 100 \\
\hline
\end{tabular}

Tabel 5. Distribusi Pasien Rawat Inap SMF THT-KL Berdasarkan pekerjaan

\begin{tabular}{llcc}
\hline No & Pekerjaan & $\mathrm{F}$ & $\%$ \\
\hline 1 & Belum/Tidak & 99 & 23,08 \\
& Bekerja & & \\
2 & Pelajar & 74 & 17,25 \\
3 & Pegawai Negeri & 77 & 17,95 \\
4 & Pegawai Swasta & 78 & 18,18 \\
5 & Pensiunan & 6 & 1,40 \\
6 & Pedagang & 22 & 5,13 \\
7 & Petani & 18 & 4,20 \\
8 & Buruh & 17 & 3,96 \\
9 & Sopir & 3 & 0,70 \\
10 & Pekerjaan Tidak & 5 & 1,17 \\
& Tetap & & \\
11 & IRT & 30 & 6,99 \\
Total & 429 & 100 \\
\hline
\end{tabular}

\section{Jenis Penyakit}

Tabel 6. Jenis Penyakit Pada Pasien Rawat Inap SMF THT-KL Tahun 2010-2012

\begin{tabular}{llll}
\hline No & Diagnosis & F & $\%$ \\
\hline 1 & Abses Auricuralis & 2 & 0,47 \\
2 & Abses Epiglotis & 3 & 0,70 \\
3 & Abses Laring & 1 & 0,23 \\
4 & Abses Lidah & 1 & 0,23 \\
5 & Abses Nasal & 3 & 0,70 \\
6 & Abses Septum Nasi & 2 & 0,47 \\
7 & Adenotonsilitis & 1 & 0,23 \\
8 & Ca Cavum Nasi & 1 & 0,23 \\
9 & Ca Esofagus & 2 & 0,47 \\
10 & Ca Laring & 5 & 1,17 \\
11 & Ca MAE Sinistra & 1 & 0,23 \\
12 & Ca Nasofaring & 21 & 4,90 \\
13 & Ca Parotis & 2 & 0,47 \\
14 & Disfagia & 6 & 1,40 \\
15 & Ekstraksi Gigi Palsu & 5 & 1,17 \\
16 & Epiglotis Akut & 1 & 0,23 \\
17 & Epistaksis & 73 & 17,02 \\
18 & Esofagitis & 2 & 0,47 \\
19 & Faringitis & 5 & 1,17 \\
20 & Faringitis Akut & 75 & 17,48 \\
21 & Fraktur Nasal & 2 & 0,47
\end{tabular}

\begin{tabular}{|c|c|c|c|}
\hline 22 & Infiltrat Peritonsiler & 1 & 0,23 \\
\hline 23 & Kista Auricular & 1 & 0,23 \\
\hline 24 & Laringitis & 9 & 2,10 \\
\hline 25 & Mastoiditis & 6 & 1,40 \\
\hline 26 & $\begin{array}{l}\text { Otitis Media } \\
\text { Kronis }\end{array}$ & 7 & 1,63 \\
\hline 27 & Otitis Media & 5 & 1,17 \\
\hline 28 & Polip Nasi & 28 & 6,53 \\
\hline 29 & Polip Tonsiltektomi & 1 & 0,23 \\
\hline 30 & Rhinitis Kronik & 3 & 0,70 \\
\hline 31 & Rhinofaringitis & 5 & 1,17 \\
\hline 32 & Septum Deformitas & 3 & 0,70 \\
\hline 33 & Sinusitis & 7 & 1,63 \\
\hline 34 & Stenosis / Granuloma MAE & 2 & 0,47 \\
\hline 35 & Tiroiditis & 64 & 14.92 \\
\hline 36 & Tonsilofaringitis & 12 & 2.80 \\
\hline 37 & Tumor Cavum Nasi & 2 & 0.47 \\
\hline 38 & Tumor Coli & 20 & 4.66 \\
\hline 39 & Tumor Faring & 2 & 0.47 \\
\hline 40 & Tumor Laring & 20 & 4.66 \\
\hline 41 & Tumor Lidah & 1 & 0.23 \\
\hline 42 & Tumor Nasal & 3 & 0.70 \\
\hline 43 & Tumor Nasi & 2 & 0.47 \\
\hline 44 & Tumor Nasofaring & 6 & 1.40 \\
\hline 45 & Tumor Palatum & 2 & 0.47 \\
\hline 46 & Tumor Plika Vokalis & 1 & 0.23 \\
\hline 47 & Tumor Telinga & 1 & 0.23 \\
\hline 48 & Tumor Tonsil Faringitis & 1 & 0.23 \\
\hline Tot & & 429 & 100 \\
\hline
\end{tabular}

Dari Tabel 6 dapat dilihat bahwa proporsi jenis penyakit berdasarkan penyakit tenggorokan 239 kasus (55,97\%), penyakit hidung 163 kasus $(38,17 \%)$ dan penyakit telinga 25 kasus (5,85\%). Jenis penyakit terbanyak faringitis akut dengan 75 kasus (17,48\%) dan terendah abses laring, abses lidah, adenotonsilitis, Ca cavum nasi, Ca MAE Sinistra, epiglottis akut, infiltrat peritonsiler, polip tonsiltektomi, tumor lidah, tumor plika vokalis, tumor telinga, dan tumor tonsil faringitis masing-masing 1 kasus ( 0,23\% ).

Pada Tabel 7 dapat dilihat bahwa jumlah sepuluh penyakit THT terbanyak adalah faringitis akut yaitu (22,94\%) dan terendah abses laring, abses lidah, adenotonsilitis, $\mathrm{Ca}$ cavum nasi, Ca MAE Sinistra, epiglottis akut, infiltrat peritonsiler, polip tonsiltektomi, tumor lidah, tumor plika vokalis, tumor telinga, dan tumor tonsil faringitis masing-masing 1 kasus yaitu (0,23\%). 
Tabel 7. Sepuluh Penyakit Terbanyak Pasien Rawat Inap SMF THT-KL Tahun 2010-2012.

\begin{tabular}{|l|l|l|l|}
\hline No & Diagnosis & F & $\%$ \\
\hline 1 & Faringitis Akut & 75 & 22.94 \\
2 & Epistaksis & 73 & 22.32 \\
3 & Tonsilitis & 62 & 18.96 \\
4 & Polip Nasi & 28 & 8.56 \\
5 & Ca Nasofaring & 21 & 6.42 \\
6 & Tumor Coli & 20 & 6.12 \\
7 & Tumor Laring & 20 & 6.12 \\
8 & Tonsilofaringitis & 12 & 3.67 \\
9 & Laringitis & 9 & 2.75 \\
10 & Sinusitis & 7 & 2.14 \\
\hline \multicolumn{2}{|l|}{ Total } & 327 & 100 \\
\hline
\end{tabular}

Dari Tabel 8 dapat dilihat bahwa proporsi pasien rawat inap yang menderita Penyakit faringitis akut terbanyak pada kelompok umur 1-9 tahun, epistaksis terbanyak pada kelompok umur 40-49 tahun dan tonsillitis terbanyak pada kelompok umur 30-39 tahun.

\section{Cara Pembiayaan}

Pada Tabel 9 dapat dilihat bahwa proporsi jaminan kesehatan terbesar adalah cara pembayaran umum yaitu $48,02 \%$ dan terendah adalah jamsostek 8,86\%.

Tabel 9. Jaminan Kesehatan Pasien Rawat Inap Penyakit THT-KL Tahun 2010-2012

\begin{tabular}{llcc}
\hline No & Jaminan Kesehatan & $\mathrm{F}$ & $\%$ \\
\hline 1 & Askes & 125 & 29,14 \\
2 & Jamkesmas & 60 & 13,99 \\
3 & Jamsostek & 38 & 8,86 \\
4 & Umum & 206 & 48,02 \\
Total & & 429 & 100 \\
\hline
\end{tabular}

Tabel 8. Sepuluh Penyakit THT-KL Terbanyak Pada Pasien Rawat Inap SMF THT-KL RSUP Prof. Dr R. D. Kandou Tahun 2010-2012 Menurut Distribusi Umur.

\begin{tabular}{|c|c|c|c|c|c|c|c|c|c|c|c|}
\hline \multirow[b]{2}{*}{ No } & \multirow[b]{2}{*}{ Diagnosis } & \multicolumn{9}{|c|}{ Umur } & \multirow[b]{2}{*}{ Jumlah } \\
\hline & & $<1$ & $1-9$ & $\begin{array}{l}10- \\
19\end{array}$ & $\begin{array}{l}20- \\
29\end{array}$ & $\begin{array}{l}30- \\
39\end{array}$ & $\begin{array}{l}40- \\
49\end{array}$ & $\begin{array}{l}50- \\
59\end{array}$ & $\begin{array}{l}60- \\
69\end{array}$ & $>70$ & \\
\hline 1 & Faringitis Akut & 8 & 54 & 9 & 1 & 0 & 0 & 0 & 0 & 3 & 75 \\
\hline 2 & Epistaksis & 1 & 6 & 5 & 7 & 10 & 19 & 13 & 6 & 6 & 73 \\
\hline 3 & Tonsilitis & 0 & 3 & 13 & 9 & 14 & 9 & 4 & 6 & 3 & 62 \\
\hline 4 & Polip Nasi & 0 & 0 & 4 & 4 & 3 & 9 & 6 & 1 & 1 & 28 \\
\hline 5 & Ca Nasofaring & 0 & 1 & 1 & 2 & 4 & 5 & 5 & 2 & 1 & 21 \\
\hline 6 & Tumor Coli & 0 & 0 & 1 & 1 & 2 & 7 & 3 & 4 & 2 & 20 \\
\hline 7 & Tumor Laring & 0 & 0 & 1 & 0 & 3 & 2 & 8 & 4 & 2 & 20 \\
\hline 8 & Tonsilofaringitis & 1 & 3 & 1 & 2 & 0 & 2 & 3 & 0 & 0 & 12 \\
\hline 9 & Laringitis & 0 & 0 & 1 & 1 & 1 & 1 & 3 & 1 & 1 & 9 \\
\hline 10 & Sinusitis & 0 & 0 & 0 & 3 & 3 & 0 & 0 & 1 & 0 & 7 \\
\hline Tot & & 10 & 67 & 36 & 31 & 40 & 54 & 45 & 25 & 19 & 327 \\
\hline
\end{tabular}

Jumlah Pasien Rawat Inap Per Tahun

Dari Tabel 10 dapat dilihat bahwa proporsi jumlah pasien rawat inap per tahun terbanyak ialah 2012 dengan 148 pasien (34,50\%). Pasien rawat inap di SMF THT-KL periode Januari 2010 - Desember 2012 berjumlah sebagai berikut: pasien yang di rawat inap pada tahun 2010 sebanyak 147 orang; pada tahun 2011 sebanyak 134 orang; dan pada tahun 2012 sebanyak 148 orang; dalam hal ini jumlah pasien rawat inap dari tahun ke tahun tidak menunjukan peningkatan yang drastis.

Tabel 10. Jumlah Pasien Rawat Inap Per Tahun Di SMF THT-KL Tahun 2010-2012.

\begin{tabular}{cccc}
\hline No & Tahun & F & $\%$ \\
\hline 1 & 2010 & 147 & 34.27 \\
2 & 2011 & 134 & 31.24 \\
3 & 2012 & 148 & 34.50 \\
& Total & 429 & 100 \\
\hline
\end{tabular}


Hal ini dapat terjadi karena banyak pasien kasus THT yang hanya melakukan rawat jalan. Pernyataan ini didukung oleh hasil penelitian yang dilakukan oleh Elisa, dkk yang melakukan penelitian pola penyakit rawat jalan di poliklinik telinga, hidung, tenggorok-bedah kepala leher di BLU RSU Prof. Dr. R. D. Kandou Manado periode januari 2010-desember 2012. Dalam penelitian ini didapatkan jumlah kunjungan pada tahun 2010 sebanyak 1761 orang, pada tahun 2011 sebanyak 2305 orang dan tahun 2012 sebanyak 1510 orang. ${ }^{3}$

Berdasarkan hasil penelitian yang ditinjau secara sosiodemografi jumlah total pasien rawat inap periode januari 2010 desember 2012 adalah 429 orang yang terdiri dari jenis kelamin laki-laki 265 orang dan perempuan 164 orang. Pasien rawat inap terbesar terdapat pada kelompok umur 40-49 tahun sebesar 35,56\% yang terdiri dari laki-laki 18,49\% dan perempuan $17,07 \%$. Sedangkan pasien rawat inap yang terendah terdapat pada kelompok umur kurang dari 1 tahun 6,1\% yang terdiri dari laki-laki 1,13 dan perempuan 4,88\%. Berdasarkan agama dan suku yang tertinggi persentasenya adalah Kristen Protestan yaitu 83,68\% dan suku Minahasa yaitu 82,28\%. Hal ini kemungkinan karena masyarakat Manado mayoritas beragama Kristen Protestan dan di dominasi oleh suku Minahasa. Berdasarkan tingkat pendidikan yang terbanyak adalah SLTA 48,95\% dan yang terendah SLTP. Berdasarkan pekerjaan yang terbanyak ialah belum atau tidak berkerja 23,08\% dan yang terendah sopir dan pekerja tidak tetap yaitu $0,70 \%$ dan $1,17 \%$. Berdasarkan hasil penelitian ini didapatkan 48 jenis penyakit THT dengan sepuluh penyakit terbanyak yaitu faringitis akut, epistaksis, tonsilitis, polip nasi, Ca nasofaring, tumor coli, tumor laring, tonsilofaringitis, laryngitis dan sinusitis. Pada penelitian ini faringitis akut merupakan penyakit ke 1 terbanyak (75 kasus) dan kasus terbanyak terjadi pada kelompok umur 1-9 tahun. Hasil penelitian ini sejalan dengan hasil penelitian Politon yang mendapatkan hasil kasus faringitis akut banyak terjadi pada kelompok umur 19 tahun yaitu 54 kasus. Menurut Journal of the American Academy of Family Physicians, faringitis akut dapat menyerang pada semua umur, penyebab faringitis yang paling sering adalah Group A Beta Hemolytic Streptococcal (GABHS) 15 hingga 30\% kasus faringitis terjadi pada anak-anak dan 5 hingga 15\% kasus terjadi pada dewasa. Pada tahun 2004 di Indonesia dilaporkan bahwa kasus faringitis akut masuk dalam 10 besar kasus penyakit yang dirawat jalan dengan presentase jumlah penderita 1,5 \% atau sebanyak 214.781 orang. Faringitis adalah peradangan dinding faring yang disebabkan oleh virus, bakteri, jamur, dan lain-lain. insiden terjadinya faringitis akibat virus adalah 40 $60 \%$ sedangkan yang disebabkan oleh bakteri sebesar 5 - 40\%. Pada anak, penyebab tersering disebabkan oleh infeksi bakteri. streptokokus beta hemolitikus grup A dengan jumlah kasus sekitar 30-40\%. Hal ini menunjukkan masih tingginya tingkat infeksi saluran pernapasan akut (ISPA) pada anak. ${ }^{5-8}$

Pada penelitian ini epistaksis merupakan penyakit ke 2 terbanyak setelah faringitis akut yaitu 73 kasus dan di dominasi oleh kelompok umur 40-49 tahun. Epistaksis biasanya ringan ada usia muda dan bertambah berat dengan meningkatnya usia. Hasil penelitian ini sejalan dengan hasil penelitian yang dilakukan sebelumnya oleh Idjie pada poliklinik THT RSUP Prof. Dr. R. D. Kandou pada tahun 2008-2009 yang mendapatkan presentasi epistaksis 16,2\%. Pada penelitian ini didapatkan hasil epistaksis 22,32\% dari seluruh penyakit THT di instalasi rawat inap. ${ }^{5}$

Epistaksis atau perdarahan dari hidung merupakan kegawatdaruratan yang umum ditemukan di bagian telinga hidung dan tenggorokan. Epistaksis diperkirakan terjadi pada $7-14 \%$ populasi umum tiap tahun. Prevalensi sebenarnya tidak diketahui disebabkan kebanyakan kasus adalah sembuh sendiri dan tidak dilaporkan. ${ }^{9}$

Pada penelitian ini juga didapatkan tonsillitis merupakan penyakit terbayak ke 
3 dari seluruh penyakit THT di instalasi rawat inap yaitu 18,96\% dengan kelompok umur terbanyak 11-19 tahun. Hasil penelitian ini sejalan dengan hasil penelitian yang dilakukan oleh Zulasvini Nurjannah yang mendapatkan $40 \%$ kasus tonsillitis terjadi pada kelompok umur 1120 tahun. Hasil penelitian ini juga sejalan dengan hasil penelitian Paradise dkk terhadap 58 penderita yang dilakukan tindakan tonsilektomi pada anak-anak, didapatkan kelompok umur terbanyak adalah 7-15 tahun sebanyak 41 (30\%) penderita. Penyakit pada tonsil palatine (tonsil) merupakan permasalahan yang umum ditemukan pada anak. Tonsilitis dapat disebabkan oleh bakteri, virus, dan penyebab infeksi maupun non infeksi lainnya. ${ }^{10,11}$

Proporsi pasien rawat inap SMF THTKL RSUP Prof. Dr. R. D. Kandou pada periode Januari 2010 - Desember 2012 berdasarkan cara pembayaran tertinggi adalah umum yaitu $48,02 \%$ dan terendah adalah jamsostek 8,86\%. Hasil penelitian ini sejalan dengan hasil penelitian yang dilakukan oleh Politon yang mendapatkan cara pembayaran pasien rawat inap 2010 tertinggi adalah umum yaitu $49,7 \%$ dan yang terendah adalah jamsostek 2,0\%. Hal ini dapat terjadi karena 78 pasien memiliki pekerjaan pegawai swasta.

Berdasarkan hasil penelitian yang dilakukan pada pasien rawat inap SMF THT-KL RSUP Prof. Dr. R. D. Kandou Manado dari tahun ke tahun terjadi perubahan pola penyakit. Pada tahun 2007 sampai dengan 2010 pola penyakit masih di dominasi oleh penyakit THT yang berhubungan dengan infeksi sedangkan pada tahun 2011-2012 penyakit THT meningkat pada penyakit yang bersifat tumor baik ganas maupun jinak diantaranya Ca nasofaring 21 kasus 6,42\%, polip nasi 28 kasus 8,56\%, tumor coli 20 kasus 6,12\% dan tumor laring 20 kasus 6,12\%.

Hasil penelitian ini mendapatkan kasus Ca nasofaring terbanyak pada kelompok umur 40-49 tahun dan 50-59 tahun. Hasil ini sejalan dengan hasil penelitian Jayapalan $^{11}$ yang mendapatkan kasus Ca nasofaring terbanyak pada usia 41-50 tahun 34,9\%. Hasil penelitian ini juga mendapatkan kasus polip nasi 28 kasus dan yang terbanyak pada kelompok usia 40-49 tahun. Hasil penelitian ini di dukung oleh hasil penelitian Fathma Dewi yang mendapatkan kasus polip nasi terbanyak terdapat pada kelompok umur 35-54 tahun. ${ }^{11}$ Untuk tumor laring pada penelitian ini didapatkan kasus terbanyak pada kelompok umur 50-59 tahun. Hasil penelitian ini sejalan dengan hasil penelitian Ernawati ${ }^{12}$ dalam penelitiannya yang berjudul ksrakteristik penderita tumor ganas laring di RSUP H. Adam Malik Medan tahun 2010-2011 yang mendapatkan kasus terbanyak tumor laring terjadi pada kelompok umur 50-60 tahun yaitu 41,7\%. Hal ini dapat terjadi akibat dari kebiasaan hidup manusia yang kurang peduli akan kesehatannya dan kesehatan lingkungan.

\section{SIMPULAN}

Dari hasil penelitian dan bahasan dapat disimpulkan bahwa dari pasien rawat inap periode 2010-2012 berdasarkan sosiodemografi yang terbanyak ialah jenis kelamin laki-laki, kelompok umur 40-49 tahun, beragama Kristen Protestan, tingkat pendidikan SLTA, belum atau tidak berkerja, dan suku Minahasa.

Berdasarkan jenis penyakit, didapatkan 48 jenis penyakit dengan 10 penyakit THT terbanyak, yaitu berturut-turut: faringitis akut, epistaksis, tonsilitis, polip nasi, Ca nasofaring, tumor coli, tumor laring, tonsilofaringitis, laringitis, dan sinusitis.

\section{DAFTAR PUSTAKA}

1. Utama S. Upaya Menghadapi Masalah Kesehatan Di Masa Depan [Skripsi]. Fakultas Kesehatan Masyarakat, Universitas Sumatera Utara; Medan, 2004.

2. Anjaryani WD. Kepuasan Pasien Rawat Inap Terhadap Pelayanan Perawat Di RSUD Tugurejo Semarang [Tesis]. Semarang: Program Studi Magister Promosi Kesehatan Kajian Sumberdaya Manusia, Program Pasca Sarjana, Universitas Diponegoro; 
2009.

3. Paembobo EEB, Mengko SK, Pelealu OCP. Pola Penyakit Pasien Rawat Jalan Di Poliklinik Telinga, Hidung, Tenggorok - Bedah Kepala Leher BLU RSU Prof. Dr. R. D. KandouManado Periode Januari 2010 Desember 2012 [Skripsi]. Manado: Fakultas Kedokteran Universitas Sam Ratulangi; 2013.

4. Kementerian Kesehatan Republik Indonesia. Profil Data Kesehatan Indonesia Tahun 2011. Jakarta, 2012.

5. Politon RO. Pola Penderita Rawat Inap THT - KL di BLU RSUP Prof. Dr. R.D. Kandou Manado Periode Januari 2010 - Desember 2010 [Skripsi]. Manado: Fakultas Kedokteran, Universitas Sam Ratulangi; 2011.

6. Fan OH. Karakteristik Penderita Faringitis Akut Di RSUP Haji Adam Malik Medan Tahun 2011-2012 [Skripsi]. Medan: Fakultas Kedokteran Universitas Sumatera Utara; 2013.

7. Kojongian S, Pelealu OCP, Tumbel R. Kesehatan Tenggorok PadaSiswa Sekolah Dasar Eben Haezer 1 Manado Dan Sekolah Dasar GMIM Bitung Amurang Kabupaten Minahasa Selatan [Skripsi]. Manado: Bagian SMF THT-KL BLU RSU Prof. Dr. R. D. Kandou Fakultas
Kedokteran Universitas Sam Ratulangi; 2013.

8. Rasmaliah. Infeksi Saluran Pernafasan Akut (ISPA) dan Penganggulangannya [Skripsi]. Medan: Fakultas Kesehatan Masyarakat Universitas Sumatera Utara; 2004.

9. Budiman JB, Yolazenia. Epistaksis Berulang dengan Rinosinusitis Kronik, Spina pada Septum dan Telangiektasis [Skripsi]. Padang: Bagian THT-KL Fakultas Kedokteran Universitas Andalas.

10.Nurjannah Z. Karakteristik Penderita Tonsilitis Kronis di RSUP H. Adam Malik Medan Tahun 2007-2010 [Skripsi]. Medan: Fakultas Kedokteran Universitas Sumatera Utara; 2011.

11.Jayapalan R. Profil Penderita Karsinoma Nasofaring di RSUP H. Adam Malik Medan Periode Januari - Desember Tahun 2012. Medan: Fakultas Kedokteran Universitas Sumatera Utara; 2013.

12.Ernawati I. Kaakteristik Penderita Tumor Ganas Laring Di RSUP H. Adam Malik Medan Tahun 2010 - 2011 [Skripsi]. Medan: Fakultas Kedokteran Universitas Sumatera Utara; 2012. 